\title{
Effect of infection with gonococci on myeloperoxidase activity of leucocytes
}

\author{
WARREN W. SCHULTZ AND DAVID W. THOMAS \\ Department of Microbiology, Naval Medical Research Institute, Bethesda, Maryland 20014, U.S.A.
}

The ability of the virulent type of Neisseria gonorrhoeae to resist or survive in the presence of the polymorphonuclear leucocyte may play a role in this organism's virulence and in the production of a carrier state. Recent studies (Thongthai and Sawyer, 1973) indicate that the virulent type (Type I) (Kellogg, Peacock, Deacon, Brown, and Pirkle, 1963) of gonococcus is more resistant to phagocytosis by human neutrophils than the avirulent type (Type IV), but both are killed when phagocytosed. In our previous study (Thomas, Hill, and Tyeryar, 1973), it was shown that a greater number of cell-associated virulent Type I $\left(T_{1}\right)$ than avirulent Type IV $\left(T_{4}\right)$ gonococci remain viable after incubation with neutrophils for $2.5 \mathrm{hrs}$ in the presence of heated serum. The viability of virulent gonococci, however, was greatly reduced when unheated serum was used. This suggests that these organisms remained so located as to be susceptible to the bactericidal action of serum.

Myeloperoxidase, a lysosomal enzyme in human neutrophils, acts synergistically with $\mathrm{H}_{2} \mathrm{O}_{2}$ and a halide to form an active bactericidal system when in direct contact with bacteria (Klebanoff and Hamon, 1972; Sbarra, Paul, Strauss, and Mitchell, 1972). When radioactive iodide is employed as the halide, an iodine compound is formed which fixes to the bacteria, and under certain conditions the degree of iodination parallels bactericidal activity due to lysosomes. This reaction, then, can be used to monitor lysosomal activity. It has also been shown (Dingle, Fell, and Coombs, 1967; Fell, 1969; Schultz, 1972) that lysosomal activation and subsequent enzyme release does not necessarily require or imply phagocytosis. Punsalang and Sawyer (1973) and Swanson (1973) demonstrated that $T_{1}$ adheres to certain mammalian cells and is not necessarily phagocytosed. It is possible that $T_{1}$ gonococci activate the lysosomal system from their extracellular location. We investigated, therefore, the difference in capabilities of $T_{1}$

Received for publication September 9, 1974

The opinions or assertions contained herein are those of the authors and are not to be construed as official or reflecting the views of the Navy Department or the Naval service at large

This study was supported by the Bureau of Medicine and Surgery, Navy Department, Research Task MR011.0001.002.0005 and $T_{4}$ to stimulate the lysosomal system of the leucocytes.

\section{Material and methods}

\section{BACTERIAL CULTURES}

For our studies the following strains of Neisseria gonorrhoeae were used: F62-T 1 and RD5-T 4 (obtained from Dr. D. S. Kellogg, Jr., Center for Disease Control, Atlanta, Ga.), a $T_{4}$ isolated in our laboratory from the F62-T: culture, and a $T_{1}$ and $T_{4}$ derived in our laboratory from ÂTCC-19424. These organisms were grown and stored as previously described (Thomas and others, 1973). The two last-named isolates are resistant to the bactericidal activity of normal human serum. For each experiment, 16 to 18-hr cultures were harvested from plates with modified Hanks's solution (MHS) (Martin and Green, 1953) that contained 0.1 per cent. crystallized bovine serum albumin glucose (HBG). A uniform suspension of bacteria was obtained by agitation for $15 \mathrm{sec}$. on a Vortex mixer in the presence of Superbrite glass beads (type 070-5005; 3M Co., St. Paul, Minn.). The bacteria were sedimented by centrifugation at $1950 \mathrm{G}$ at $25^{\circ} \mathrm{C}$. for $10 \mathrm{~min}$. and re-suspended in HBG to the desired concentration. Serially diluted samples of the working suspension were plated to ensure that bacterial viability was at least 90 per cent. in a given experiment.

\section{LEUCOCYTES AND SERA}

Human leucocytes and sera were obtained from adult male donors with no previous history of gonococcal infection and with a negative indirect fluorescent antibody test (H. A. Gaafar and D. D'Arcangelis, Abstr. Annu. Meet. Amer. Soc. Microbiol., p. 114, 1972; performed by Dr. W. D. Lawton, New York State Department of Health). Serum fractions were prepared by standard DEAE-cellulose ion exchange chromatography and ammonium sulphate precipitation. The fractions were tested for relative immunoglobulin composition by the Mancini radial immunodiffusion method (Mancini, Carbonara, and Heremans, 1965). Leucocytes were obtained by dextran sedimentation of peripheral blood. About $35 \mathrm{ml}$. blood were collected by venepuncture into a plastic syringe containing $20 \mathrm{ml}$. heparinized $(25 \mathrm{U}$ per ml.) MHS containing 3 per cent. dextran 150 (Pharmacia, Uppsala, Sweden). The syringe was placed in an upright position for $30 \mathrm{~min}$. at room temperature. The leucocyterich fraction was removed and the cells sedimented by centrifugation at $150 \mathrm{G}$ for $10 \mathrm{~min}$. at $32^{\circ} \mathrm{C}$. The pelleted 
cells were re-suspended in heparinized distilled water for $20 \mathrm{sec}$. to lyse any residual red blood cells and an equal volume of double strength heparinized HBG was then added. The suspension was centrifuged at $250 \mathrm{G}$ for $10 \mathrm{~min}$. at $22^{\circ} \mathrm{C}$. and the sedimented leucocytes were then re-suspended to the desired concentration in HBG. Neutrophils represented about 80 to 90 per cent. of the cells in the final suspension and viability ranged from 95 to 99 per cent. as determined by dye exclusion $(0 \cdot 15$ per cent eosin $\mathrm{Y}$ ).

\section{MYELOPEROXIDASE TECHNIQUE}

The myeloperoxidase technique employed was a modification of Klebanoff's procedure (Klebanoff, 1967). The reaction mixtures were placed in twelve $75 \mathrm{~mm}$. plastic tubes and contained the following: 3 to $5 \times 10^{8}$ neutrophils, 10 per cent. serum or HBG, gonococci at ratios of 5 to 15 per neutrophil and about $2 \mu \mathrm{Ci}$ of carrier-free ${ }^{125}$ iodine in a total volume of $0.5 \mathrm{ml}$. Each reaction was performed in triplicate. After rotary incubation (110 rpm for $30 \mathrm{~min}$. at $37^{\circ} \mathrm{C}$.) the samples were washed four times by centrifugation and re-suspension, once in HBG (250 G for $10 \mathrm{~min}$. at $22^{\circ} \mathrm{C}$.) and thrice with ice-cold 5 per cent. trichloroacetic acid ( $390 \mathrm{G}$ for $10 \mathrm{~min}$. at $5^{\circ} \mathrm{C}$.). The counts per minute (cpm) of ${ }^{25}$ iodine in the precipitates after the fourth washing were determined in a gamma counter.

\section{Results}

Table I illustrates typical results of leucocyte lysosomal myeloperoxidase activity as determined by the amount of iodination obtained when using serum- resistant strains of virulent and avirulent gonococci. With the avirulent type much greater myeloperoxidase activity was observed than with the virulent type in the absence of serum. There was a large increase in the activity induced by the virulent type when heated serum was added while there was no increased activity with $T_{4}$. In the case of $T_{1}$, the activity began to approach that of $T_{4}$ when complement or other heat labile serum substances were present. When incubation time was extended to $60 \mathrm{~min}$. there was little change in activity induced by $T_{4}$ with or without unheated serum, whereas a 2 to 3-fold increase occurred with $T_{1}$.

Table II shows the effect of bacterial multiplicity on myeloperoxidase activity. A pair of serum-sensitive strains were used in this experiment. It can be seen that with $\mathrm{T}_{4}$ there was increased myeloperoxidase activity, whereas with $T_{1}$ there was little further stimulation of activity with higher multiplicity. As was observed with serum-resistant gonococci, $T_{1}$ serumsensitive gonococci stimulated to a much lesser extent than $T_{4}$ and serum enhanced the activity induced by $T_{1}$. Unheated serum was not used here because it is bactericidal for these strains in the absence of leucocytes.

An attempt was made to determine which serum fraction was responsible for the increased activity observed when gonococci were incubated in the presence of serum (Table III). Fraction I contained

TABLE I Myeloperoxidase activity of human leucocytes incubated with gonococci

\begin{tabular}{|c|c|c|c|c|c|c|}
\hline \multirow[t]{4}{*}{ Experiment } & \multirow{2}{*}{\multicolumn{2}{|c|}{$\begin{array}{l}\text { Serum added } \\
\text { (per cent.) }\end{array}$}} & \multicolumn{4}{|c|}{ Colonial type } \\
\hline & & & \multicolumn{2}{|l|}{$T_{1}$} & \multicolumn{2}{|l|}{$T_{4}$} \\
\hline & \multirow{2}{*}{ Heated $^{\mathrm{a}}$} & \multirow{2}{*}{ Unheated } & \multicolumn{2}{|c|}{ Time (min.) } & \multicolumn{2}{|c|}{ Time (min.) } \\
\hline & & & 30 & 60 & 30 & 60 \\
\hline 1 & $\begin{array}{r}-10 \\
5 \\
-\end{array}$ & $\begin{array}{r}- \\
-5 \\
10\end{array}$ & $\begin{array}{l}(c p m \\
1 \cdot 6^{\mathrm{c}} \\
32^{\mathrm{d}} \\
65 \\
86\end{array}$ & porated ${ }^{125} I$ ) & $\begin{array}{r}81 \\
69 \\
95 \\
103\end{array}$ & \\
\hline 2 & - & $\overline{10}$ & $\begin{array}{l}2 \cdot 8 \\
37\end{array}$ & 71 & $\begin{array}{l}167 \\
128\end{array}$ & $\begin{array}{l}159 \\
157\end{array}$ \\
\hline
\end{tabular}

st $56^{\circ} \mathrm{C}$. for $30 \mathrm{~min}$.

bDerived from ATCC 19424 and resistant to the bactericidal activity of normal serum. Multiplicity of inoculation in both experiments:5

cMeans of three samples after subtraction of leucocyte background and gonococcus background

dThese reactions were inhibited by $0.20 \mathrm{mM}$ sodium cyanide

TABLE II Myeloperoxidase activity of human leucocytes incubated with increasing numbers of gonococci

\begin{tabular}{|c|c|c|c|c|}
\hline Serum added ${ }^{\mathrm{a}}$ & Strain $\mathbf{b}$ & \multicolumn{3}{|c|}{ Gonococcal multiplicity per leucocyte } \\
\hline None & $\begin{array}{l}\text { F62-T }_{1} \\
\text { RD5-T }_{4}\end{array}$ & $\begin{array}{c}(c p m \\
1 \cdot 3 \\
38\end{array}$ & $\begin{array}{c}\left.d^{125} I\right) \\
0 \cdot 7 \\
72\end{array}$ & ${ }_{91}^{2 \cdot 7}$ \\
\hline 10 per cent. & $\begin{array}{l}\text { F62-T } \\
\text { RD5-T }\end{array}$ & $\begin{array}{l}25 \\
46\end{array}$ & $\begin{array}{l}29 \\
74\end{array}$ & $\begin{array}{r}39 \\
129\end{array}$ \\
\hline
\end{tabular}

a Heated at $56^{\circ} \mathrm{C}$. for $30 \mathrm{~min}$.

both strains susceptible to the bactericidal activity of normal serum 
only IgG, Fraction II contained a mixture of IgG, IgA, and IgM, and Fraction III contained no measurable immunoglobulins. Crystallized bovine serum albumin was used as an additional control. Fraction I, and to a less extent Fraction II, was stimulatory and this stimulation can be attributed to IgG. Fraction I was at least as active as whole serum despite its much lower total protein. As in previous experiments, activity stimulated by $T_{4}$ strains was greater than that by $T_{1}$. Fraction III stimulated activity to a small extent or not at all and in the case of $T_{1}$ was comparable to that in the absence of serum (not shown). These results were obtained with both serum-sensitive and serum-resistant strains.

\section{Discussion}

Thongthai and Sawyer (1973) reported that $T_{4}$ gonococci, which are non-pilated, are phagocytosed more readily than the pilated $T_{1}$. The results of our previous investigation (Thomas and others, 1973) with the same strains of gonococci and the same host cell donors clearly indicate that $T_{1}$ gonococci adhere to the outer surface of the neutrophil whereas $T_{4}$ are phagocytosed. These results were confirmed by Punsalang and Sawyer (1973) and Swanson (1973) who demonstrated that $T_{1}$ actually adhere to various mammalian cells. Our results here are compatible with these findings, that is, $T_{4}$ is readily taken into the cell and this event leads to a high level of myeloperoxidase or lysosomal activity, whereas with $T_{1}$ a significant fraction of the population adheres to the surface and the results are variable.

In the absence of serum, $T_{1}$ stimulated very little or negligible lysosomal activity. Activity was stimulated to a considerable extent, however, in the presence of serum, particularly IgG. This was true of serumsusceptible as well as serum-resistant strains. This effect appeared to be qualitatively different from activity stimulated by $T_{4}$. In the latter case, enhancement by serum was not always observed and, in contrast to $T_{1}$, was dependent (within limits) on multiplicity of infection. From the results cited above (Thomas and others, 1973; Punsalang and Sawyer, 1973; Swanson, 1973), together with our current findings, it appears that $T_{1}$ can stimulate lysosomal activity from its extracellular position. For this stimulation serum (heated or unheated) is required but, in most cases, the activity is less than that observed with intracellular $\mathrm{T}_{4}$. Ward, Watt, and Glynn (1970) have shown that gonococci in urethral exudates are serum resistant. The extracellularly stimulated lysosomal activity may, therefore, be a killing mechanism for serum-resistant, membrane-associated gonococci and may account for some of the increased killing of $T_{1}$ that we previously observed when these organisms were incubated in the presence of serum.

\section{Summary}

Lyosomal myeloperoxidase activity in human phagocytic leucocytes was stimulated by incubation with virulent $\left(T_{1}\right)$ and avirulent $\left(T_{4}\right)$ forms of Neisseria gonorrhoeae. The amount of activity, assayed by bacterial iodination ( ${ }^{125}$ iodine) after $30 \mathrm{~min}$. exposure to the phagocytes in the absence of serum, was about fifty times greater in cells infected with $\mathrm{T}_{4}$ strains. In the presence of heated human serum, or its IgG component, myeloperoxidase activity increased, but $T_{1}$-stimulated activity was significantly less than that of $T_{4}$ and was not proportional to multiplicity of infection. From these results and from those of a previous study we conclude that $T_{1}$ can stimulate leucocyte myeloperoxidase activity from an extracellular location, that for this activity a serum fraction is required, and that this may be a mechanism responsible for some of the killing of the membrane associated $\mathrm{T}_{1}$.

The authors acknowledge the help of Dr. E. Weiss in the preparation of this manuscript, Dr. R. Wistar in the preparation of the serum fractions, and the technical assistance of Mr. M. Powell.

TABLE III Myeloperoxidase activity of human leucocytes incubated with various serum fractions

\begin{tabular}{|c|c|c|c|c|c|}
\hline \multirow[t]{3}{*}{ Strain } & \multirow{3}{*}{$\begin{array}{l}\text { Whole } \\
\text { serum }^{\mathrm{a}}\end{array}$} & \multicolumn{3}{|l|}{ Fractions } & \multirow{3}{*}{$\begin{array}{l}\text { Crystallized bovine } \\
\text { serum albumin }\end{array}$} \\
\hline & & I & II & III & \\
\hline & & $\begin{array}{l}\mathrm{IgG} \\
7 \mathrm{mg} / \mathrm{ml}\end{array}$ & $\begin{array}{l}49 \% \text { IgG } \\
29 \% \text { IgA } \\
22 \% \text { IgM } \\
8 \mathrm{mg} / \mathrm{ml}\end{array}$ & $\begin{array}{l}\text { No IgG } \\
\text { IgA or } \\
\text { IgM } \\
16 \mathrm{mg} / \mathrm{ml}\end{array}$ & \\
\hline $\begin{array}{l}\text { F62-T } \\
\text { RD5-T } \\
\text { F62-T }_{1} \\
\text { F62-T } \\
\text { ATCC-T }_{1} \\
\text { ATCC- }_{4}\end{array}$ & $\begin{array}{l}18 \\
40 \\
13 \\
18 \\
25 \\
79\end{array}$ & $\begin{array}{r}12 \\
49 \\
28 \\
45 \\
23 \\
161\end{array}$ & $\begin{array}{c}11 \\
19 \\
6 \cdot 6 \\
15 \\
4 \cdot 1 \\
39\end{array}$ & $\begin{array}{l}\text { incorporated }{ }^{125} I \text { ) } \\
3 \cdot 2 \\
21 \\
0 \cdot 1 \\
9 \\
3 \cdot 2 \\
\text { Not done }\end{array}$ & $\begin{array}{l}1 \cdot 9 \\
32 \\
0 \cdot 4 \\
8 \\
4 \cdot 3 \\
\text { Not done }\end{array}$ \\
\hline
\end{tabular}

aHeated at $56^{\circ} \mathrm{C}$. for $30 \mathrm{~min}$. 


\section{References}

Dingle, J. T., Fel., H. B., and Coombs, R. R. A. (1967) Int. Arch. Allergy, 31, 283

Fell, H. B. (1969) In'Harry Steenbock Symposium on The Fat Soluble Vitamins', ed.H. F. de Luca and J. W. Suttie, p. 187-202. University of Wisconsin Press, Madison

Kellogg, D. S., Peacock, W. L., Deacon, W. E., Brown, L., and PIRKLE, C. I. (1963) F. Bact., 85, 1274

KLEBANOFF, S. J. (1967) f. exp. med., 126, 1063

$\longrightarrow$, and HAMON, C. B. (1972) f. reticuloendothel. Soc., 12, 170

mancini, G., Carbonara, A. O., and Heremans, J. F. (1965) Int. f. Immunochem., 2, 325

MARTIN, S. P., and GREEN, R. (1958) Methods med. Res., 7, 136

Punsalang, A. P., Jr., and Sawyer, W. D. (1973) Infect. and Immun., 8, 255

Sbarra, A. J., Paul, B. B., Jacobs, A. A., Strauss, R. R., and MITCHELL, G. W. (1972) f. reticuloendothel. Soc., 12, 109

SCHULTZ, W. W. (1972) Dissertation: 'Virus-induced lysosomal enzyme dissolution of chick nasal turbinate cartilage'. Welch Medical Library, Johns Hopkins University, Baltimore

Swanson, J. (1973) f. exp. Med., 137, 571

Thomas, D. W., Hill, J. C., and Tyeryar, F. J., Jr. (1973) Infect. and Immun., 8, 98

ThongthaI, C., and SAWYER, W. D. (1973) Ibid., 7, 373

WARD, M. E., WATT, P. J., and GlyNN, A. A. (1970) Nature (Lond.), 227, 382 